\title{
E-learning Delivery Platforms for Improving Teaching/Learning During COVID-19 Lockdown in Private Universities, South-South Nigeria
}

\author{
Effiong Edet Asuquo and Rosemary Young Godwin
}

\section{ABSTRACT}

Published Online: July 24,2021

ISSN:2736-4534

DOI :10.24018/ejedu.2021.2.3.109

\author{
Dr. Effiong Edet Asuquo \\ Department of Business Education, \\ Faculty of Education, University of Uyo, \\ Nigeria. \\ (e-mail: drasuquoee ${ }^{\circledR}$ gmail.com) \\ Rosemary Young Godwin \\ Department of Business Education, \\ University of Uyo, Nigeria. \\ (e-mail: rosavaileyoung@gmail.com)
}

Keywords: COVID-19, E-learning, Google Classroom, Virtual Classroom and Zoom.

\section{INTRODUCTION}

Corona Virus (COVID-19) was first reported in Nigeria on the $27^{\text {th }}$ of February 2020 when an Italian man who arrived from Milan, Italy tested positive for the dreaded virus. Since March 2020 when the nationwide lockdown was instituted by the Federal Government of Nigeria (FGN) due to Corona virus outbreak, there was also a total industrial unrest in the nation's Public Universities against the Integrated Payroll and Personnel Information System (IPPIS).Public Universities were eventually shut down due to the National Strike by the Academic Staff Union of Universities (ASUU) against the supposed forceful migration of University staff to the IPPIS salary payment platform. This period witnessed a daily increase of corona virus cases in the country.

Private Universities equally shut down though temporarily to curtail the spread of the virus. After a short while, the Private Universities reopened and resorted to using e-learning in order not to disrupt their academic calendar as was the case with Public Universities. According to Obayi [1], e-learning is an innovative form of learning/teaching that uses Information Communication Technology (ICT) as an interactive forum to effect teaching/learning without the physical presence of both learners and teachers in a structured environment. Otukpo [2] observes that e-learning which is an electronic learning deals with the use computer, Android, Information Operating System (IOS), and other devices to effect teaching /learning in such a manner that the teacher is not confined in a single environment with the student and that these devices help the student to learn at their pace.

Most Private Universities had the infrastructure for online teaching and learning. They had no difficulties in resuming their normal academic activities during the lockdown period. Many of them developed and innovated the Zoom technologies to enable teaching/learning to take place. Zoom is an application that allows conferences and discussion to take place without the physical presence of learners and the teachers. According to Brown [3], the zoom technology is a google enabled platform that allows for effective delivery of instructive materials to students and also allows the effective use of feedback mechanism. Owolkanke[4] opined that the zoom makes use of its video call and conferencing facilities where the host system can have access to the system of other participants. The host (teacher/lecturer) will create a password and access code and distribute to the students through the social media or text messages. In the message, the time and duration of the class would be included. The student would then log in and participate actively in the class.

Another form of e-learning used during the COVID-19 lockdown by Private Universities is the google classroom. Benson [5] stated that the google classroom is a free web service developed by google for schools that want to simplify, create, distribute, and grade assignments. The primary purpose of google classroom is to streamline the process of sharing files between teachers and students. Google classroom was released publicly in August 12, 2014, its 
operating systems are android, IOS, web and is purposefully created for education.

The google classroom integrates Docs, sheets, slides, Gmail, and calendar into a cohesive platform to manage students and teacher communication,Olu [6]. Students can be invited to join a class through a private code, or automatically imported from a school domain. Teachers can create, distribute, and mark assignments all within the google ecosystem. Each class creates a separate folder in the respective users drive, where the student can submit work to be graded by a teacher. Assignments and due dates are added to google calendar, each assignment can belong to a category (or topic). Teachers can monitor the progress of each student by reviewing the revision history of a document and after being graded, teacher can return work along with comments, John [7].

The virtual classroom involves all other forms that do not encourage the students to be present in the classroom system. Virtual classroom is usually associated with online courses or online environment, but it has much broader dimensions. Virtual classroom is a learning experience that is enhanced through utilizing computers and/or the internet both outside and inside the facilities of the educational organization,Bryan [8].The teaching activities are carried out online whereby the teacher and learners are physically separated in terms of place, time, or both. The virtual classroom was mostly used in the Private Universities during the COVID-19 lockdown. It is on this background that this research was conducted.

It is interesting to note that while Public Universities were totally under lock and key due to the COVID-19 and ASUU strike that lasted for close to ten (10) months, Private Universities were on with their academic activities due to the fact that they had infrastructures which enabled them to quickly adopt the online learning approach. The innovative approach was however strange and alien to both the students and the lecturers who were hitherto used to the traditional classroom methods. How well this innovation was utilized to engender effective teaching and learning process in the Private Universities leaves much to be desired. It is against this background that this study is being carried out.

\section{PURPOSE OF THE STUdY}

The main purpose of the study was to examine the extent to which e-learning delivery platforms were utilized to improve teaching/learning during COVID-19 lockdown in Private Universities in South-South, Nigeria. Specifically, the study sought to:

i. Determine the extent to which zoom technology was utilized to improve teaching /learning during COVID-19 lockdown in Private Universities, South-South Nigeria. ii. Determine the extent to which google classroom was utilized to improve teaching /learning during COVID-19 lockdown in Private Universities, South-South Nigeria. iii. Determine the extent to which virtual classroom was utilized to improve teaching /learning during COVID-19 lockdown in Private Universities, South-South Nigeria.

\section{RESEARCH QUESTION}

The following research question were asked by the researchers to guide the study:

i. To what extent was zoom technology utilized to improve teaching/learning during COVID-19 lockdown in Private Universities, South-South Nigeria?

ii. To what extent was google classroom utilized to improve teaching/learning during COVID-19 lockdown in Private Universities, South-South Nigeria?

iii. To what extent was virtual classroom utilized to improve teaching/learning during COVID-19 lockdown in Private Universities, South-South Nigeria?

\section{RESEARCH METHODS}

An expost-facto survey design was used to collect data for the study. This is because the researchers made use of an already existing data and the use of questionnaire to get response from the respondents. The study was conducted in South-South Nigeria. The South-South region is the oil hub of the Federal Republic of Nigeria. The South-South Region is popularly called the Niger Delta Region. The Niger Delta comprises of six states namely, Akwa Ibom State, Cross Rivers State, Rivers State, Edo State, Delta State and Bayelsa State.The area is of great interest to the researchers because, the area has characteristics and samples which are of great interest to the researchers. The population of this study consisted of all 4305 students of five Private Universities in South-South Nigeria (Source: gotten from their respective universities in South-South, Nigeria). A sample size of 366 was used by the researchers through cluster sampling technique. The sample size was derived using Taro Yamane formula.A structured instrument titled "Utilization of Elearning platform for Teaching/Learning during the Covid-19 Lockdown Questionnaire" (UEPTDCOVID19LQ) was used for the study. The instrument was validated by three research experts in the Department of Business Education, University of Uyo. The contributions and inputs from the experts were incorporated into final draft of the study. A Cronbach alpha reliability test was used to test the instrument to determine the reliability of the instrument. A reliability coefficient of 0.79 was gotten. The researchers employed five (5) research assistants to help distribute the questionnaires to the subjects in Private Universities selected in Rivers and Edo State while the researchers concentrated in the Private Universities in Akwa Ibom State. A high return rate of $95 \%$ was gotten from the field. Mean statistics was used to answer the research questions.

\section{RESULTS}

\section{A. Research Question 1}

To what extent was zoom technology utilized to improve teaching/learning during COVID-19 lockdown in Private Universities, South-South Nigeria? 
TABLE I: MEAN STATISTICS FOR ANSWERING RESEARCH QUESTION 1N=366

\begin{tabular}{|c|c|c|c|c|}
\hline $\mathrm{S} / \mathrm{N}$ & Statements & 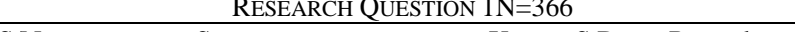 & $\mathrm{SD}$ & Remarks \\
\hline 1 & $\begin{array}{l}\text { Zoom was used in live teaching } \\
\text { of courses }\end{array}$ & 4.81 & 3.11 & $\begin{array}{l}\text { Very Great } \\
\text { Extent }\end{array}$ \\
\hline 2 & Zoom was installed in all our & 4.96 & 2.78 & Very Great \\
\hline 3 & $\begin{array}{l}\text { Zoom technology was used in } \\
\text { examining us }\end{array}$ & 4.90 & 2.18 & $\begin{array}{l}\text { Very Great } \\
\text { Extent }\end{array}$ \\
\hline 4 & $\begin{array}{l}\text { Zoom was utilized in sending } \\
\text { and receiving feedback }\end{array}$ & 4.85 & 3.16 & $\begin{array}{l}\text { Very Great } \\
\text { Extent }\end{array}$ \\
\hline 5 & $\begin{array}{l}\text { Zoom was utilized in faculty } \\
\text { meetings with students }\end{array}$ & 4.96 & 3.21 & $\begin{array}{l}\text { Very Great } \\
\text { Extent }\end{array}$ \\
\hline & Grand Mean & 4.90 & & $\begin{array}{l}\text { Very Great } \\
\text { Extent }\end{array}$ \\
\hline
\end{tabular}

From the data analysis in Table I, all the items are above the mean cut-off of point of 2.50. The grand mean of 4.90 showed that zoom was utilized to a very great extent to improve teaching and learning during the Covid-19 lockdown in Private Universities.

\section{B. Research Question 2}

To what extent was google classroom utilized to improve teaching/learning during Covid -19 lockdown in Private Universities, South-South Nigeria.

TABLE II: MEAN STATISTIC FOR ANSWERING RESEARCH QUESTION $2 \mathrm{~N}=366$

\begin{tabular}{|c|c|c|c|c|}
\hline S/N & Statements & $\mathrm{X}$ & S.D. & Remarks \\
\hline 1 & $\begin{array}{c}\text { Google classroom was used in } \\
\text { teaching/ learning }\end{array}$ & 3.11 & 2.96 & $\begin{array}{c}\text { Great } \\
\text { Extent }\end{array}$ \\
\hline 2 & $\begin{array}{c}\text { Google classroom was used in } \\
\text { feedback }\end{array}$ & 2.16 & 1.67 & $\begin{array}{l}\text { Great } \\
\text { Extent }\end{array}$ \\
\hline 3 & $\begin{array}{l}\text { Google classroom was utilized } \\
\text { in having meetings }\end{array}$ & 1.67 & 0.19 & $\begin{array}{l}\text { Very little } \\
\text { Extent }\end{array}$ \\
\hline 4 & $\begin{array}{c}\text { Google classroom was used in } \\
\text { assignments }\end{array}$ & 1.20 & 0.05 & $\begin{array}{l}\text { Very Little } \\
\text { Extent }\end{array}$ \\
\hline \multirow[t]{2}{*}{5} & $\begin{array}{c}\text { Google classroom was utilized } \\
\text { in examinations }\end{array}$ & 1.60 & 0.21 & $\begin{array}{l}\text { Very Little } \\
\text { Extent }\end{array}$ \\
\hline & Grand Mean & 1.95 & & $\begin{array}{l}\text { Very Little } \\
\text { Extent }\end{array}$ \\
\hline
\end{tabular}

From the data analysis on Table II, the items (except item 1) fell below the cut-off point of 2.50. The grand mean of 1.95 shows that google classroom was utilized to a very little extent to improve teaching/learning during the COVID-19 lockdown in Private Universities.

\section{Research Question 3}

To what extent was virtual classroom utilized to improve teaching/learning during COVID-19 lockdown in Private Universities, South-South Nigeria?

TABLE III: MEAN STATISTIC FOR ANSWERING RESEARCH QUESTION 3N=366

\begin{tabular}{|c|c|c|c|c|}
\hline $\mathrm{S} / \mathrm{N}$ & Statements & $X$ & S.D. & Remarks \\
\hline 1 & $\begin{array}{l}\text { Virtual classroom involves the } \\
\text { absence of subjects }\end{array}$ & 4.85 & 1.70 & $\begin{array}{l}\text { Very Great } \\
\text { Extent }\end{array}$ \\
\hline 2 & $\begin{array}{l}\text { Virtual classes were carried } \\
\text { out in Covid-19 }\end{array}$ & 4.98 & 3.11 & $\begin{array}{l}\text { Very Great } \\
\text { Extent }\end{array}$ \\
\hline 3 & $\begin{array}{l}\text { Virtual tests were given by } \\
\text { lecturers }\end{array}$ & 4.85 & 3.12 & $\begin{array}{l}\text { Very Great } \\
\text { Extent }\end{array}$ \\
\hline 4 & $\begin{array}{l}\text { Lecturers make use of virtual } \\
\text { facilities for classes }\end{array}$ & 4.88 & 3.4 & $\begin{array}{l}\text { Very Great } \\
\text { Extent }\end{array}$ \\
\hline \multirow[t]{2}{*}{5} & $\begin{array}{l}\text { Meeting between students } \\
\text { were done using virtual }\end{array}$ & 4.98 & 3.60 & $\begin{array}{l}\text { Very Great } \\
\text { Extent }\end{array}$ \\
\hline & Grand Mean & 4.90 & & $\begin{array}{l}\text { Very Great } \\
\text { Extent }\end{array}$ \\
\hline
\end{tabular}

From the data analysis in Table III, it can be seen that all the items are above the mean cut-off of point of 2.50. The grand mean of 4.90 showed that virtual classroom was utilized to a very great extent to improve teaching/learning by private Universities during the COVID-19 lockdown.

\section{Findings of the Study}

The following are finding for the study

1. Zoom application was utilized to a very great extent during the COVID-19 lockdown to improve teaching/learning in Private Universities, SouthSouth Nigeria.

2. Google classroom was utilized to a very low extent during the COVID-19 lockdown to improve teaching/learning of in Private Universities, SouthSouth Nigeria.

3. Virtual classroom was utilized to a very great extent during the COVID-19 lockdown to improve teaching/learning in Private Universities, SouthSouth Nigeria.

\section{E. Discussion of the Findings}

The data analysis indicated that Zoom application was used in teaching and learning of courses in Private Universities, South-South Nigeria. This study showed that majority of the Private Universities made use of zoom applications in their academic activities. This finding agreed with Brown [3] who stated that the use of Zoom helps in the teaching and learning at the student pace.

The data analysis in Table II indicated that google classroom was not fully utilized in the teaching/learning of courses in Private Universities. This was due to the fact that google classroom was an emerging technology in the Nigeria educational system. The google classroom is still in the stage of adoption. This agrees with Owolkanke [4] who stated that google classroom is still at the emerging stage.

Finally, the data analysis on Table 3 shows that virtual classroom was frequently used in teaching and learning of students. These findingsagree with Bryan [8]who hosted virtual classroom as models for teaching/learning in virtual spaces.

\section{CONCLUSION}

The study has shown that Private Universities utilized elearning facilities during the COVID-19 lockdown because they had ICT infrastructures that could facilitate teaching/learning without having the Lecturers and students physically present in the classroom. The study had shown that zoom application was greatly utilized because of its acceptability and ease of use by both Lecturers and students. Google classroom was seldom used due to the fact that it is an emerging technology and finally virtual classroom was greatly utilized during the period under review. From the study it is clear that e-learning facilitates teaching/learning significantly and improves learning process. The Private Universities were able to utilize e-learning delivery platform during the lockdown period to ensure that their academic activities were not completely disrupted as was the case in Public Universities. It is also observed that platforms for 
teaching/learning in tertiary institutions are yet to fully utilize e-learning.

\section{F. Recommendations}

The following recommendations were given by the researchers:

1. Government should help develop infrastructures in Public Universities.

2. Students should endeavor to be ICT compliant by at least owning a laptop.

3. Parents should enroll their children in ICT lessons in order to fully adopt and operate such.

4. Lecturers should be trained on ICT in learning.

\section{References}

[1] A. U.Obayi, "Database and Database Management System". Enugu: Rivan, 2021.

[2] B., Otukpo,"E-learning Platforms for Continuing Education in Covid-19". Journal ofMediterraneanSociety,2(3): 111-126, 2021.

[3] Brown B. (2021). Zoom for Beginners 2020/2021: A Step by Step Guide to Easy Start Virtual Meeting with Zoom. Available at: https://brightslidebookshop.com. Retrieved on March 31 ${ }^{\text {st }}, 2021$.

[4] U. Owolkanke, "Delivery Content in Information Computer Technology Era". Journal of Science Education, 5(3): 26-31, 2021.

[5] O. Benson,"Information Computer Technology in Schools". Lagos: Jojan, 2021

[6] A. J. Olu, "Information Computer Technology Development for Teaching and Learning". Journal of Educational Technology, 1(2): 57-60, 2018.
[7] C. K. John, "Computerized Form of Teaching and Learning". Journal of Computer Education, 7(3): 7-12, 2016.

[8] A. Y. Bryan, "Virtual Learning for Productive Results". Lagos: Academic Press, 2009.

[9] O. Biodun, "Federal Government Demands ASUU Suspend Strike before Negotiation". Available at: https://www.thisdaylive.com. Retrieved on March 31 2021.

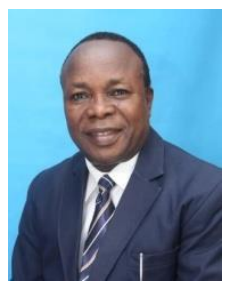

Effiong Edet Asuquo is an Associate Professor of Business Education. He is a professional member of Association of Vocational and Technical Educators of Nigeria (AVTEN) and Association of Business Educators of Nigeria (ABEN).

He has served as Editor of different volumes of journals and has published many articles in Peer Review Journals, both locally and internationally. Dr. Asuquo graduated with a Bachelor of Education Degree in Business Education from Ahmadu Bello University, Zaria. He did his masters and PhD Degrees in University of Nigeria, Nsukka. Dr. Asuquo teaches in University of Uyo and has served the University in various capacities. He is the current coordinator of Post Graduate programme in the Department of Business Education. He is married to a lovely wife and blessed with five intelligent children.

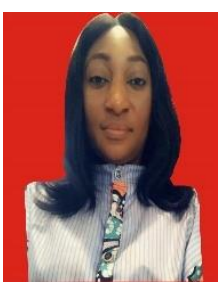

Rosemary Young Godwin is a Ph. D Student of University of Uyo, Uyo, Akwa Ibom State, Nigeria. She holds a Master's Degree in Business Education, a Bachelor Degree in Business Education (Accounting).

She is a chartered member of Nigerian Institute of Management (NIM) and a license member of Teachers Registration Council of Nigeria (TRCN). 